\title{
Go-CART: an animal-free system for the assessment of CAR T cell function
}

\author{
Pradip Bajgain ${ }^{*}$, Usanarat Anurathapan ${ }^{1}$, Ayumi Watanabe1, John Wilson², Sujita Sukumaran ${ }^{1}$, Norihiro Watanabe ${ }^{1}$, \\ Helen Heslop ${ }^{1}$, Cliona Rooney ${ }^{1}$, Malcolm Brenner ${ }^{1}$, Ann Leen ${ }^{1}$, Juan Vera ${ }^{1}$ \\ From 30th Annual Meeting and Associated Programs of the Society for Immunotherapy of Cancer (SITC 2015) \\ National Harbor, MD, USA. 4-8 November 2015
}

The preclinical development of chimeric antigen receptor (CAR) $\mathrm{T}$ cell therapy has been hindered by the inadequacy of current in vitro methods to predict $\mathrm{T}$ cell performance (i.e. migration, proliferation and anti-tumor activity), which do not recapitulate in vivo conditions. For example, most $\mathrm{T}$ cell functional assays are performed over a relatively short timeframe (6-18 hrs), and platforms to assess $\mathrm{T}$ cell migration and prolonged $\mathrm{T}$ cell-tumor cell interactions are very restricted. To overcome these deficits, we developed the Go-CART an in vitro, compartmentalized culture system that allows long-term assessment of multiple biological para- meters simultaneously. The Go-CART is a six chambered device (C1-C6) connected by $2 \mathrm{~mm}$ channels that form an "S" shaped, $11.5 \mathrm{~cm}$ path, allowing the generation of a chemokine gradient (Figure 1). Thus, $\mathrm{T}$ cells and tumor cells can be physically separated, allowing for simultaneous in vitro assessment of $\mathrm{T}$ cell migration, anti-tumor effects, and persistence. Furthermore, the gas-permeable base of the Go-CART allows for prolonged $\mathrm{T}$ cell-tumor cell interaction ( $>2$ weeks) without medium/nutrient replenishment.

To explore whether we could establish a chemokine gradient in the Go-CART, we added $24 \mu \mathrm{g}$ of MCP1 to

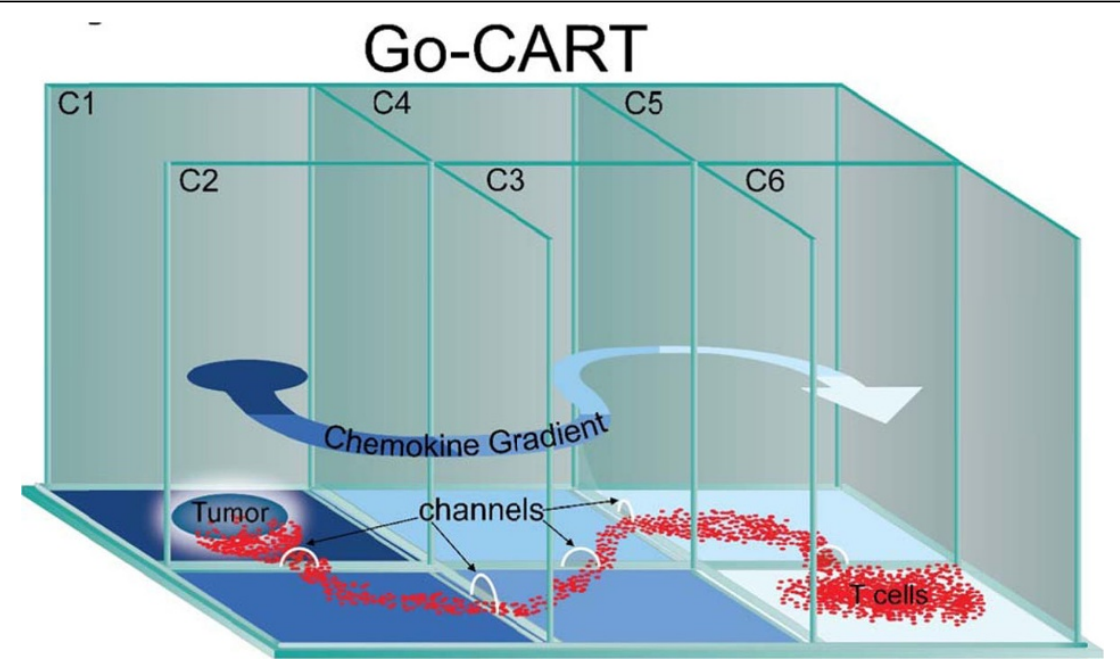

Figure 1

${ }^{1}$ Baylor College of Medicine, Houston, TX, USA

Full list of author information is available at the end of the article

(c) 2015 Bajgain et al. This is an Open Access article distributed under the terms of the Creative Commons Attribution License (http:// 
compartment $1(\mathrm{C} 1)$ and evaluated the chemokine levels in all compartments. After 72 hours, we observed the formation of a gradient that could drive $\mathrm{T}$ cell migration (196.79, 78.52, 56.80, 9.79, 2.52 and 0.64ng/ml MCP1, C1-C6, respectively). Next, to assess whether T cell migration could be induced by chemokine-producing tumor cells, we established a 3D tumor model (AlgiMatrix seeded with 1.00E+06 CAPAN1 tumor cells) in $\mathrm{C} 1$ and three days later, added 2.00E+07 CAR-PSCA-FFluc-GFP T cells to C6. We monitored $\mathrm{T}$ cell migration by periodic bioluminescence imaging and after 5 days, observed an accumulation of T cells at the tumor site (C1) $(7.69 \mathrm{E}+06$ and 3.19E $+08 \mathrm{p} / \mathrm{s} / \mathrm{cm}^{2} / \mathrm{sr}$, days 1 and 5 , respectively). In contrast, $\mathrm{T}$ cells failed to localize in the absence of tumor cells. Finally, to assess the utility of the Go-CART in evaluating anti-tumor effects, we established an AlgiMatrix-3D tumor model in C1 with 1.00E+06 CAPAN1-FFLuc-GFP tumor cells and three days later, added $2.00 \mathrm{E}+07$ CAR-PSCA T cells to C6. Under these conditions, we observed a progressive decrease in the tumor signal [3.52E +08 (day 0) and $3.31 \mathrm{E}+07$ (day 15$\left.) \mathrm{p} / \mathrm{s} / \mathrm{cm}^{2} / \mathrm{sr}\right]$. In contrast, in the absence of $\mathrm{T}$ cells, the tumor signal progressively increased $[2.69 \mathrm{E}+08$ (day 0 ) to $2.47 \mathrm{E}+09$ (day 15$\left.) \mathrm{p} / \mathrm{s} / \mathrm{cm}^{2} / \mathrm{sr}\right]$. Thus, our results demonstrate that the Go-CART can be used to dynamically assess multiple parameters required for CAR T cell function.

\section{Authors' details}

${ }^{1}$ Baylor College of Medicine, Houston, TX, USA. ${ }^{2}$ Wilson Wolf Corporation, New Brighton, MN, USA.

Published: 4 November 2015
Submit your next manuscript to BioMed Central and take full advantage of:

- Convenient online submission

- Thorough peer review

- No space constraints or color figure charges

- Immediate publication on acceptance

- Inclusion in PubMed, CAS, Scopus and Google Scholar

- Research which is freely available for redistribution

Submit your manuscript at www.biomedcentral.com/submit 